\title{
BACTERIAL INVASION AS A KEY FACTOR IN PROGRESSION OF REACTIVE ARTHRITIS ON EXAMPLE OF CLINICAL CASE
}

Osman H. A., Golubkina E. O., Silenko I. Y., Yabluchanskiy M. I.

V. N. Karazin Kharkiv National University, Kharkiv, Ukraine

A clinical case of middle age male diagnosed with reactive arthritis developed on the background of multiple bacterial invasions such as Salmonella enterica, Ureaplasma urealyticum, Mycoplasma hominis, Borrelia burgdorferi sensu lato and characterized by chronic persistent course of the disease with destructiveinflammatory changes in the joints. This case illustrates the influence of bacterial pathogens on the course and the progression of reactive arthritis.

KEY WORDS: reactive arthritis, bacterial infections, chronic arthritis

\section{БАКТЕРІАЛЬНА ІНВАЗІЯ, ЯК КЛЮЧОВИЙ ФАКТОР У ПРОГРЕСУВАННІ РЕАКТИВНОГО АРТРИТУ НА ПРИКЛАДІ КЛІНІЧНОГО ВИПАДКУ}

Осман Х. А., Голубкіна С. О., Сіленко І. Ю., Яблучанський М. І.

Харківський національний університет імені В. Н. Каразіна, м. Харків, Україна

Клінічний випадок реактивного артриту у чоловіка середнього віку, який розвинувся на тлі багаторазових бактеріальних інвазій таких як Salmonella enterica, Ureaplasma urealyticum, Mycoplasma hominis, Borrelia burgdorferi sensu lato, та характеризувався хронічним стійким перебігом захворювання 3 деструктивно-запальними змінами в суглобах. Цей кліничний випадок іллюструє вплив бактеріальних патогенів на перебіг та прогресування реактивного артриту.

КЛЮЧОВІ СЛОВА: реактивний артрит, бактеріальні інфекції, хронічний артрит

\section{БАКТЕРИАЛЬНАЯ ИНВАЗИЯ КАК КЛЮЧЕВОЙ ФАКТОР В ПРОГРЕССИРОВАНИИ РЕАКТИВНОГО АРТРИТА НА ПРИМЕРЕ КЛИНИЧЕСКОГО СЛУЧАЯ}

Осман Х. А., Голубкина Е. А., Силенко И. Ю., Яблучанский Н. И.

Харьковский национальный университет имени В. Н. Каразина, г. Харьков, Украина

Клинический случай реактивного артрита у мужчины среднего возраста, который развился на фоне многократных бактериальных инвазий, таких как Salmonella enterica, Ureaplasma urealyticum, Mycoplasma hominis, Borrelia burgdorferi sensu lato и характеризовался хроническим персистирующим течением заболевания с деструктивно-воспалительными изменениями в суставах. Этот клинический случай иллюстрирует влияние бактериальных патогенов на течение и прогрессирование реактивного артрита.

КЛЮЧЕВЫЕ СЛОВА: реактивный артрит, бактериальные инфекции, хронический артрит

\section{INTRODUCTION}

Reactive arthritis (ReA) is a condition associated with bacterial infections of the urogenital and gastrointestinal tract, which trigger the onset of the disease, and also play a role in the progression of pathological processes in the musculoskeletal system [1-2].

Reactive arthritis (formerly known as Reiter disease) is characterized as a sterile inflammation of the synovial membrane, tendons and fascia triggered by an infection on a distant site, usually gastrointestinal (GI) or urogenital [1].

It is frequently associated with the human leukocyte antigen (HLA-B27) haplotype and is classified in the category of seronegative spondyloarthropathies. It predominantly affects young adults in the 20-40 age groups, men more than women (ratio 3:1) [3]. ReA has been 
associated with gastrointestinal (GI) infections often caused by Shigella, Salmonella, Campylobacter, as well as with genitourinary (GU) infections (Chlamydia Trachomatis, Neisseria gonorrhoeae, Ureaplasma urealyticum) and others. Adolescents and young men are most likely to develop $\mathrm{ReA}$ after a genitourinary infection, whereas young children tend to have the postdysenteric form [4]. The mechanism by which the interaction of the inciting organism with the host leads to the development of ReA is not known. There are several pathogenetic theories that include [4]:

- Molecular mimicry theory (similarity exists at the molecular level between the HLAB27 molecule and the inciting organisms, allowing the triggering of an immune response);

- Role of HLA-B27 as a receptor for certain bacteria;

- Defective class I antigen-mediated cellular response (HLA-B27 molecule may be a defective molecule associated with an aberrant cytotoxic T-cell response).

The clinical picture of reactive arthritis ranges from a mild localized condition to a severe multisystem lesions. Involvement of the joints varies from a transient monoarthritis to a widespread polyarthritis involving the peripheral and axial joints with or without characteristic extra-articular lesions, particularly enthesopathy, psoriasiform mucosal, and cutaneous lesions, inflammatory eye disease, and cardiovascular lesions [3]. The onset is usually acute and characterized by malaise, fatigue, and fever. It usually develops 1-4 weeks after a genitourinary (GU) or gastrointestinal (GI) infection. A history or evidence of recent infection is critical to the diagnosis.

The classic triad of symptoms (noninfectious urethritis, arthritis, and conjunctivitis) is found in only one third of patients with ReA and has a sensitivity of $50.6 \%$ and a specificity of $98.9 \%$ [5].

Articular lesions are characterized as asymmetrical, predominantly lower-extremity arthritis with redness, swelling, pain and warmth in and around the affected joint; it is distributed primarily in feet, ankles, knees, sacroiliac joints; hands, hips, and spine are less frequently involved. Dactylitis with so called «sausage digits» may develop. Enthesopaties are important feature of ReA and can be seen in near $30 \%$ of cases; enthesitis is usually described as tenderness, with or without swelling at the sites of tendon or fascial attachments, especially the Achilles tendon and plantar fascia attachments to the calcaneum [1]. Urogenital symptoms may be primary or postdysenteric and may include initial nongonococcal urethritis, with frequency, dysuria, urgency, and urethral discharge; cystitis, prostatitis, vulvovaginitis, cervicitis, salpingo-oophoritis and circinate balanitis (balanitis circinata) consisting of small shallow painless ulcers of the urethral meatus or the glans penis which is characteristic feature of reactive arthritis. Eye lesions often are presented as conjunctivitis, reactive iritis, episcleritis, veitis; ophthalmologic symptoms may include erythema, burning, tearing, photophobia, pain, and decreased vision.

Lesions of skin and mucosae include keratoderma blennorrhagicum, hyperkeratosis, onychodystrophy, psoriasis-like skin lesions, erosions of lips, tongue, cheeks mucosae. Cardiovascular involvement usually is rare; it can be presented as myocarditis, endocarditis, seldom - as aortitis with subsequent aortic insufficiency.

Diagnostics of reactive arthritis is based on the recognition of the typical clinical features of spondyloarthropathy and evidence of urogenital infection (symptoms and signs of urethritis and microscopic confirmation by a Gram-stained urethral smear; mucopurulent cervicitis in women) or gastrointestinal infections (stool culture).

Essential investigations include: full screening for sexually transmitted infections (STIs), including HIV; gastrointestinal infections; full blood count and acute phase response panel; urinalysis (to check for renal pathology); synovial fluid analysis which is usually used in cases where septic arthritis is suspected. Often used investigations are: HLAB27 analysis; X-rays of affected joints, spine, sacroiliac joints, ultrasonography of affected joints, entheses; electrocardiogram (ECG), ophthalmic evaluation including slit lamp assessment, liver and kidney function tests [1].

There is no specific treatment for reactive arthritis. Treatment options include lifestyle modifications with restriction of physical activity, especially weight-bearing activity in acute period with further physiotherapy after improvement of symptoms [1]. Essential is to identify and treat triggering infections: antimicrobial therapy for infection identified - 
macrolides, tetracyclines, fluoroquinolones are considered as the most effective $[1,6]$. As symptomatic therapy are used NSAIDs and corticosteroids. Sulphasalazine, methotrexate are indicated in severe cases where disabling symptoms persist for three or more months.

Prognosis varies but typically reactive arthritis has a self-limited course, with resolution of symptoms by 3-12 (usually 4-6) months. The presence of HLA-B27 and infections triggered by Yersinia, Salmonella, Shigella, Chlamydia may predict a more prolonged course and severe outcome. A fatal outcome is seldom reported. ReA has a high tendency to recur (15-50\% of cases), particularly in HLA-B27 - positive patients. A new infection or other stress factor could cause reactivation of the disease. About $15-30 \%$ of patients with ReA develop a long-term, sometimes destructive, arthritis or enthesitis or spondylitis [4].

\section{OUR CASE}

Male patient, 43 years old complains of dull pain in the knee, ankle, hip joints, in the cervical, lumbosacral spine, morning stiffness of the joints for 2,5 to 3 hours. The pain is permanent, more pronounced in the right knee and right hip joints, worsens with movements, decreases with the intake of NSAIDs (diclofenac).

Also patient complains on swelling and pain in his left wrist that worsens when he fists his hand.

Anamnesis of the disease. The patient considers himself ill from July 2010 when 2 weeks after suffering Salmonellosis first acutely appeared pain in the right knee, ankle joints, lower back pain, right heel pain and burning, redness of both eyes. Patient denied the presence of urethritis. He did not seek medical help, occasionally took NSAIDs. In November 2010 joint pain worsened, right hip become affected; after referral to a rheumatologist, he was admitted to Kharkiv hospital \#28, where high titers of mycoplasma and ureaplasma were detected (ELISA and PCR). Was made the diagnosis of urogenital reactive arthritis and he was treated with doxycyclin, NSAIDS, dexamethasone. His state has improved but still there was moderate pain and slight limitation of joint mobility. He continued treatment under the supervision of rheumatologist but his symptoms persisted and in 2011 after inpatient treatment the diagnosis of chronic reactive arthritis was made. In December 2012 the patient tried to «increase the immunity» by eating raw eggs and was hospitalized with diagnosis: Salmonellosis, associated with Salmonella enterica, serovar Paratyphi B variant Java, gastroenterictis of moderate severity (17.12.2012-25.12.2012). Subsequently he had hospitalization with diagnosis: Lime's disease (associated with Borrelia burgdorferi sensu lato), chronic course (26.12-15.01.13). After this the patient's state worsened significantly - intensified pain in affected joints with enlargement, redness, restriction of movements; also become affected left wrist joint, temperature increased up to $37,4^{\circ} \mathrm{C}$. In January 2013 he had inpatient treatment in rheumatology department with the diagnosis: Reactive arthritis, chronic course, activity of 2 grade, polyarthritis, right-sided sacroiliitis $2 \mathrm{~d}$ grade, functional impairment of 2 degree. The patient was treated with methotrexate, sulphasalazine. Subsequently, the patient was annually hospitalized in a rheumatology department.

Anamnesis of life. Patient is not working, denies smoking, alcohol and drug abuse. Postponed diseases: URVI, tonsillectomy at the age of 9 years. He denies viral hepatitis, tuberculosis, AIDS. Had no traumas, surgeries, allergic reactions.

Objective examination. General state of the patient is of moderate severity due to his articular status. Patient is oriented to the time, place, himself. He uses a cane for walking; Tredelenburg gait is present. Height $-191 \mathrm{~cm}$ weight $-90 \mathrm{~kg}, \mathrm{BMI}-24.7 \mathrm{~kg} / \mathrm{m} 2 ; \mathrm{t}-36,8^{\circ} \mathrm{C}$. Skin: pale, clean; skin turgor, moistness is preserved; visible mucous membranes are clean, moist; subcutaneous adipose tissue is developed moderately, distributed symmetrically. Lymphatic nodes are not palpable. No edemas. Thyroid gland is not enlarged. Lungs: resonance percussion sound, vesicular breathing over both lungs fields, RR - 17 per minute. Heart borders on percussion are not enlarged, heart tones are clear, loud, rhythmic; BP dex $129 / 85$, BP sin - 130/85, radial pulse is synchronous, rhythmic at $88 \mathrm{bpm}$. Abdomen is painless on superficial and deep palpation in all regions. Liver at the costal margin, painless; spleen is not palpable. Pasternatskiy sign is negative on both sides. Urination is free, painless.

Musculo-skeletal system examination. Left wrist is moderately swollen, slightly 
painful on palpation and when the patient fists his hand; there is no increased skin temperature or skin color changes. Vertebral column: scoliotic posture; spine mobility: Schober test $15 \mathrm{~cm}$. Pelvis and hip joints: there is a right lateral pelvic tilt; Tredelenburg gait is present; pelvis compression tests are positive on the right side. Knee joints: smoothness of the contours, edema, crepitation during movement more pronounced in the right knee, increased skin temperature above the right knee joint. Ankle joints: smoothness of contours, puffiness, more pronounced on the right, tenderness in palpation with slight restriction of movements; there are signs of Achilles tendinitis. Range of movements (table)

Range of movements in joints

Table

\begin{tabular}{|l|c|c|c|}
\hline \multicolumn{1}{|c|}{ Type of movement } & Hip joints & Knee joints & Ankle joints \\
\hline Flexion (flex) & Right: $120^{\circ}$, left: $110^{\circ}$ & Right: $90^{\circ}$, left: $90^{\circ}$ & Right: $120^{\circ}$, left: $120^{\circ}$ \\
\hline Extension (ext) & Right: $150^{\circ}$, left: $160^{\circ}$ & Right: $160^{\circ}$, left: $170^{\circ}$ & Right: $80^{\circ}, 1$ left: $80^{\circ}$ \\
\hline Normal range (ext/flex) & $180^{\circ} / 75^{\circ}$ & $180^{\circ} / 40^{\circ}$ & $70^{\circ} / 130^{\circ}$ \\
\hline
\end{tabular}

The results of current patient's investigations: full blood count: increased ESR: $38 \mathrm{~mm} / \mathrm{h}(\mathrm{N}-2-15 \mathrm{~mm} / \mathrm{h})$; urinalysis, fasting plasma glucose, liver function tests, kidney function tests - all parameters within the normal range; acute phase response panel: increased CRP: 12 ( $\mathrm{N}-<5)$, seromucoid: 5,9 S-H (N - 1-5 S-H); serological tests: positive ANA (antinuclear antibodies), HLA-B27 was negative. Blood analysis for urogenital infections: PCR (polymerase chain reaction): DNA of Ureaplasma urealyticum, Mycoplasma hominis is detected; ELISA (enzyme-linked immunosorbent assay): Mycoplasma hominis IgG - 2,623 (positive), Ureaplasma urealyticum $\mathrm{IgG}-0,941$ (positive). Microprecipitation test of blood serum for syphilis, HIV test - negative. ECG: sinus rhythm with $\mathrm{HR}-74$, electric axis of the heart - normal position, no pathological changes. X-ray of cervical spine in lateral flexion: height and structure of intervertebral spaces is not changed, compaction, uneven deflection of the closure plates in the articular joints. Conclusion: initial signs of spondylarthrosis. X-ray of knee joints: moderately pronounced uneven joint space narrowing (JSN), subchondral sclerosis, thickening of soft tissues more pronounced on the right. Conclusion: bilateral gonarthrosis of 2nd degree. X-ray of ankle joints: thickening of the joint capsule, articular cleft not altered. X-ray of sacroiliac and hip joints (Figure 1): Moderately pronounced uneven joint space narrowing (JSN) of the right sacroiliac joint, subchondral sclerosis, marginal erosions of the closure plates; hip joints - significant JSN of both joints more pronounced on the right side, subchondral sclerosis, osteophytes, areas of destruction of the head of the right femur. Conclusion: signs of coxarthrosis - right-sided - 4 degree, left-sided - 3 degree, right-sided sacroiliitis 2 degree, aseptic necrosis of the head of the right femur. Right lateral pelvis tilt (vertical axis $-4,5^{\circ}$, horizontal axis $-3^{\circ}$ ).

Consult of orthopedist-surgeon: right-sided coxarthritis 3-4degree; persistent severe pain syndrome; hip replacement is recommended.

Diagnosis: Reactive arthritis (since 2010) associated with urogenital infection (ureaplasmosis, mycoplasmosis), chronic continuously-relapsing course, 2nd grade of activity, polyarthritis with knee joints lesions (bilateral gonarthrosis of 2nd degree), ankle joints lesions, hip joints lesions(right-sided coxarthrosis $4^{\text {th }}$ grade, left-sided $-3^{\mathrm{d}}$ grade), unilateral right-sided sacroileitis $2^{\mathrm{d}}$ grade, functional impairment 2 degree. Disability $3^{\mathrm{d}}$ degree. 


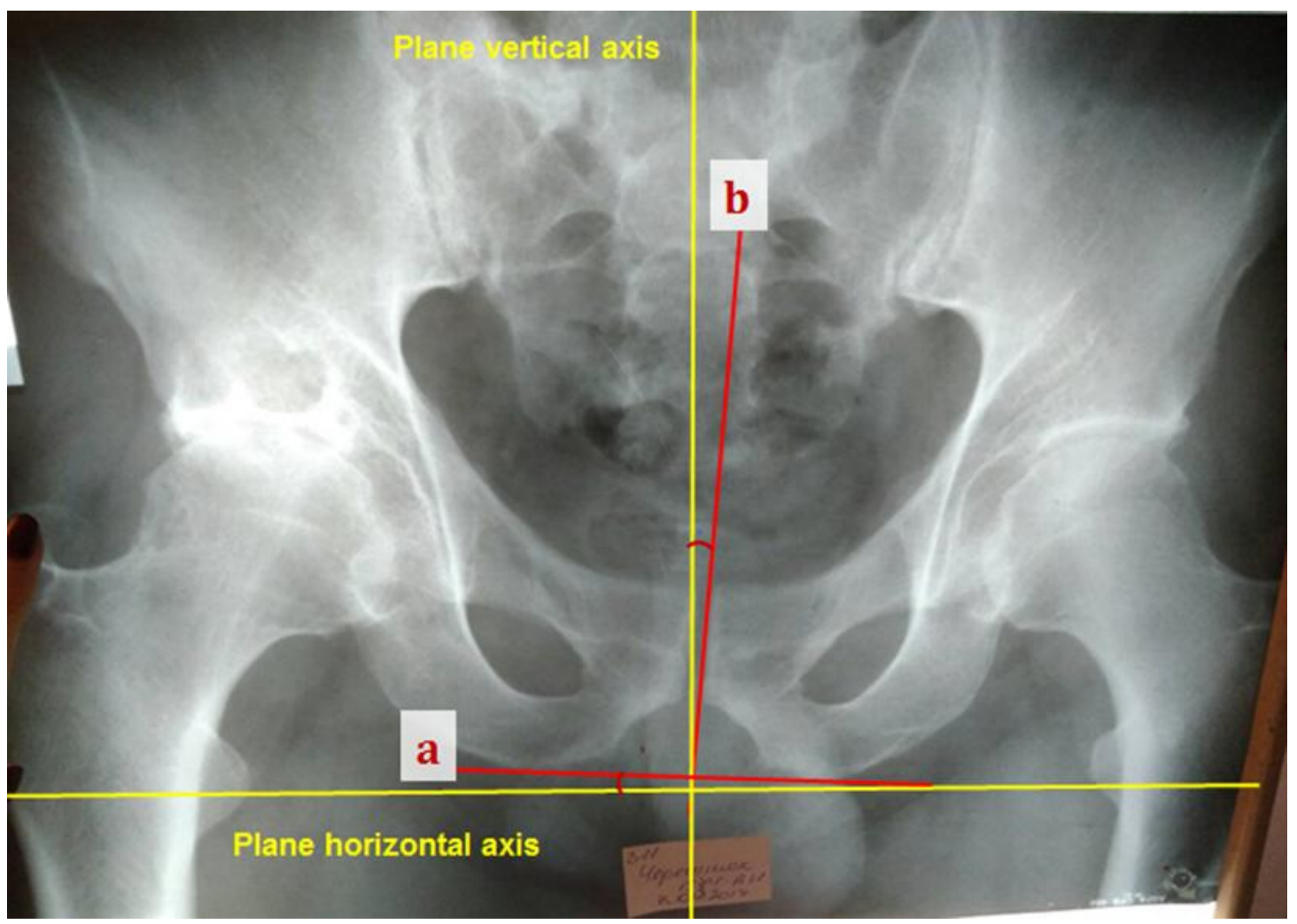

Fig. 1. X-ray of sacroiliac and hip joints; a - horizontal axis of the pelvis, b - vertical axis of the pelvis

Treatment plan. Physical activity under the supervision of a physical therapist; avoid overcooling, insolation. Drug therapy: metotrexate $10 \mathrm{mg}$ per week continuously; folic acid $5 \mathrm{mg}$ per day - next day after metotrexate; diclofenac sodium $75 \mathrm{mg} 2$ times per day; methylprednizolone $8 \mathrm{mg}$ per day continuously; hondroitine-sulphate $500 \mathrm{mg}$ twice daily 1month; calcium and D3 - combined preparation (calcium carbonate $1250 \mathrm{mg}$, cholecalciferol (vitamin D3) - $10 \mu \mathrm{g}(400 \mathrm{IU})) 1 \mathrm{tab}$ 2 times per day for 2 months.

Surgical intervention - right hip replacement is recommended.

\section{DISCUSSION}

The etiologic factor in the development of reactive arthritis remains the subject of discussion mainly due to the fact that in addition to known pathogens such as Trichomonas, Escherichia or serotypes of Salmonella with proved influence on the occurrence of reactive arthritis [1-4, 7-9] role of such pathogens as Mycoplasma and Borrelia remains controversial. It is known [1-4, 7-8] that Salmonella (and in particular Salmonella enterica serovars Typhimurium enteritidis, Paratyphi B and C, and others) is a triggering agent for the development of reactive arthritis. Incidence of reactive arthritis due to Salmonella varies up to $14 \%$, and according to some data up to $30 \%$, depending on the type of Salmonella [2, 8-9]. In addition, it was found that Salmonella infection correlated with a sufficiently high risk of chronic course of the disease: thus, according to a 20-year study [2], Salmonella induced chronic reactive arthritis was observed in $19 \%$ of cases. The role of Ureaplasma urealyticum in the development of reactive arthritis is also confirmed [1, 9-12]. According to the studies [13], Ureaplasma urealyticum was found in $26.6 \%$ of patients with reactive arthritis. However, most often there is a mixed infection, while ureaplasma monoinfection is detected in minority of cases [9].

The influence of Mycoplasma hominis and Borrelia burgdorferi on the development of reactive arthritis is controversial. These pathogens for a long time were not ranked among the infectious agents associated with reactive arthritis [14]. However, some 
researchers [2, 15] indicate a link between infection with these microorganisms and reactive arthritis, identifying them in a separate group of probable potential agents. While according to $[9,11-12,16-17]$, Mycoplasma hominis infection and the chronic infection caused by Borrelia burgdorferi are considered as a trigger factor for the development of reactive arthritis.

The course of reactive arthritis in our patient was associated with such infectious agents as Salmonella enterica, Ureaplasma urealyticum,
Mycoplasma hominis, Borrelia burgdorferi sensu lato; the presence of several bacterial pathogens, as well as re-infection with Salmonella, had a significant effect on the formation of resistance of autoimmune disorders and, as a consequence, a pronounced inflammatory response.

The analysis of the patient's ESR dynamic changes from the moment when the diagnosis was made in 2010 till 2017 confirms this (Figure 2).

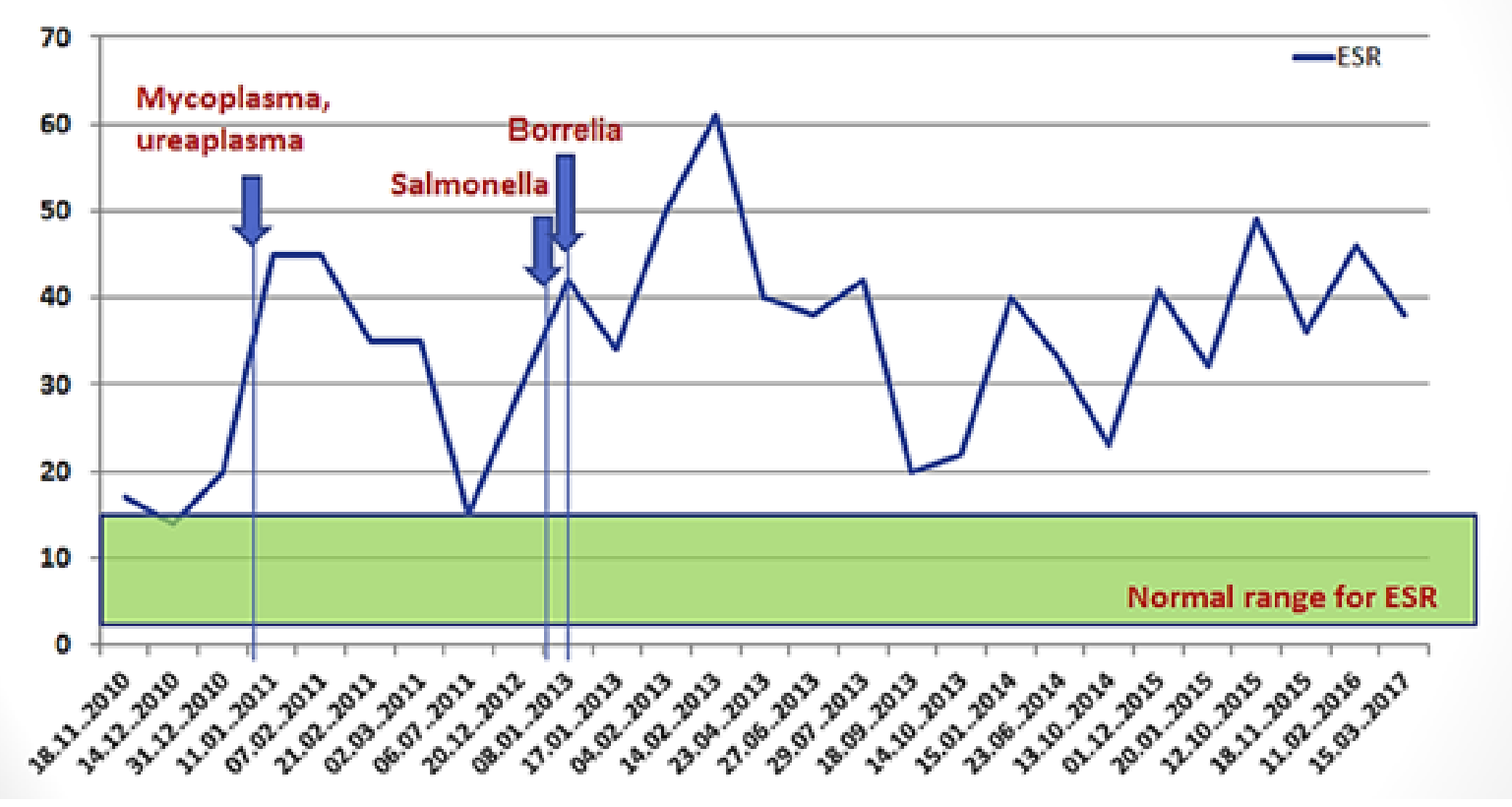

Fig. 2. Correlation between bacterial invasions and dynamic changes of ESR (2010-2017 yrs)

An increase in ESR above $30 \mathrm{~mm} / \mathrm{h}$, hip joints involvement, unresponsiveness to nonsteroidal anti-inflammatory drugs, lumbar spine stiffness, dactylitis, and the onset of the disease before the age of 16 are considered to be the factors affecting the chronicity of the disease which is usually observed in 15-30\% of patients with ReA [3-4].

The course of reactive arthritis in our patient was characterized by persistent pain and joints inflammation with involvement of hip joints and the absence of a long-term positive effect from NSAIDs therapy, a steady increase in the inflammatory markers and ESR. Progression of the disease correlated with episodes of repeated infections (see Figure 2), which led to the chronicity of the pathological process and, as a result, to destructive articular changes, a sharp deterioration in the quality of life and the need for surgical treatment.

Thus, this clinical case confirms the important role of bacterial infections in the pathogenesis of reactive arthritis, and gives new information about influence of several pathogens on the course and the progression of the disease.

\section{CONCLUSIONS}

In our patient, reactive arthritis was characterized by a chronic persistent course with a constant increase in inflammatory markers and destructive-inflammatory changes in the joints.

An important role in the progression of reactive arthritis in this patient played multiple bacterial invasions, which were not only a trigger of the onset of the disease, but also 
maintained a chronicity of the pathological processes.

This clinical case is an illustration of the fact that infectious bacterial diseases play a key role in the pathogenesis of reactive arthritis, and repeated bacterial infections affect the course and progression of the disease, which leads to a significant disruption of the function of the musculoskeletal system.

It is important to treat the patient with avoidance of polypharmacy; this goal is achieved by the appointment of several basic drugs and a supportive therapy used in courses.

\section{REFERENCES}

1. Carlin E.M. 2014 European Guideline on the management of sexually acquired reactive arthritis/ E.M. Carlin, J.M. Ziza, A. Keat [et al.] // International Journal of STD \& AIDS. - 2014. - Vol. 25 (13). p. $901-912$.

2. Colmegna I. HLA-B27-Associated Reactive Arthritis: Pathogenetic and Clinical Considerations / I. Colmegna, R. Cuchacovich, L. R. Espinoza // Clinical microbiology reviews. - 2004. - Vol. 17 (2). p. 348-369.

3. Hamdulay S. S. When is arthritis reactive? / S. S. Hamdulay, S. J. Glynne, A. Keat // Postgrad Med J. 2006. - Vol.82 (969). - p. 446-453.

4. Reactive arthritis. [electronic resource]/ [C. J. Lozada, M. F. Carpintero, R. A. Schwartz] // Medscape. 2017. - Access to resourse: https://emedicine.medscape.com/article/331347-overview.

5. Wu I. B. Reiter's syndrome: the classic triad and more. / I. B. Wu, R. A. Schwartz // J Am Acad Dermatol. - 2008. - No. 59 (1). - p. 113-21.

6. Nomenklatura, klasifikacija, kriterii diagnostiki ta programi likuvannja revmatichnih hvorob. / Pod red. V. M. Kovalenko, N. M. Shuba // Kiïv. - 2004. - s. 117-119.

7. Tuompo R. Reactive arthritis following Salmonella infection: a population-based study. / R. Tuompo, T. Hannu, L. Mattila [et al.] // Scandinavian Journal of Rheumatology. - 2013. - Vol. 42 No. 3. - p. 196202.

8. Ekman P. Modification of disease outcome in salmonella-infected patients by HLA-B27 / P. Ekman, J. Kirveskari, K. Granfors // Arthritis \& Rheumatism. - 2000. - Vol. 43 No. 7. - p. 1527-1534.

9. Spas'ka G.O. Reaktivnij artrit: suchasnij poglyad na problem. / G.O. Spas'ka // Ukraïns'kij medichnij chasopis. - 2011. - No. 6 (86). - S. 42-48.

10. Horowitz S. Ureaplasma urealyticum in Reiter's syndrome. / S. Horowitz, J. Horowitz, D. TaylorRobinson // The Journal of Rheumatology. - 1994. - No. 21 (5). - p. 877-882.

11. Butrimiene I. Potential triggering infections of reactive arthritis./ I. Butrimiene, J. Ranceva, A. Griskevicius // Scand J Rheumatol. - 2006. - No.35 (6). - p. 459-462.

12. Vorushilina I. E. Tetrada priznakov pri bolezni Rejtera: klinicheskoe nablyudenie. / I. E. Vorushilina, M. I. Mazharova, A. V. Odinec // Medicinskij vestnik severnogo kavkaza. - 2011. - No. 2. - p. 88-90.

13. Bolezn' Rejtera: sovremennye podhody k lecheniyu. [electronic resource] / [G. M. Bondarenko] // Dermatovenerologiya. - 2009. - Access to resourse: https://kiai.com.ua/ru-issue-article-271/BoleznReytera-sovremennye-podhody-k-lecheniyu.

14. Taylor-Robinson D. The association of Mycoplasma hominis with arthritis. / D. Taylor-Robinson, B. J. Thomas, P. M. Furr [et al.]// Sex Transm Dis. - 1983. - No. 10 (4). - p. 341-344.

15. Sibilia J. Reactive arthritis or chronic infectious arthritis? / J. Sibilia, F-X. Limbach // Ann Rheum Dis. 2002. - No. 61. - p. 580-587.

16. Sukumar Mukherjee Reactive Arthritis: Current Perspectives. / Mukherjee Sukumar, Kar Madhuchanda // Journal, Indian Academy of Clinical Medicine. - 2000. - Vol. 1 No. 3. - p. 233-238.

17. Weyand Cornelia M. Immune responses to Borrelia burgdorferi in patients with reactive arthritis / Cornelia M. Weyand, Jorg J. Goronzy // Arthritis \& Rheumatism. - 1989. - Vol. 32 No. 9. - p. 10571064. 